\title{
In vitro study of the antimicrobial activity of European propolis against Paenibacillus larvae
}

\author{
Valery A. IsIDOROv ${ }^{1}$, Krzysztof BuCZEK ${ }^{2}$, Grzegorz ZAMBROwSKI ${ }^{3}$, \\ Krzysztof MiastKowski ${ }^{1}$, Izabela SwIECICKA ${ }^{3,4}$ \\ ${ }^{1}$ Forest Faculty, Białystok University of Technology, 17-200, Hajnówka, Poland \\ ${ }^{2}$ Department of Epizootiology and Clinic of Infectious Diseases, Faculty of Veterinary Medicine, University of Life \\ Sciences, Lublin, Poland \\ ${ }^{3}$ Department of Microbiology, University of Bialystok, Bialystok, Poland \\ ${ }^{4}$ Laboratory of Applied Microbiology, University of Bialystok, Bialystok, Poland
}

Received 14 August 2016 - Revised 1 November 2016 - Accepted 22 November 2016

\begin{abstract}
Typical European propolis is an antibiotic substance derived from the resin of poplar, birch, and aspen buds. Here, we tested the ability of propolis originating from the resins of these plants to inhibit the in vitro growth of Paenibacillus larvae, the organism that causes American foulbrood, a fatal honeybee larval disease. The study involved GC-MS analysis of extracts from nine samples of propolis gathered from the temperate climate zone of Europe. The extracts showed noticeable differences in the content of flavonoids and other phenolic compounds. Despite the differences in chemical composition, all tested extracts inhibited the growth of $P$. larvae, with a minimum inhibitory concentration of 7.8 to $62.4 \mu \mathrm{g} \mathrm{mL}{ }^{-1}$. It was found that not only did the content of flavonoids affect the strength of antimicrobial activity, but other phenolics, such as the phenylpropenoids hydroxycinnamyl sesquiterpenols, glycerides and benzoates also had an effect. This is the first report on the comparative activity of different types of European propolis against P. larvae.
\end{abstract}

\section{Paenibacillus larvae / American foulbrood / Apis mellifera / propolis / antibacterial action}

\section{INTRODUCTION}

American foulbrood (AFB), a disease of honeybee larvae, has been known for more than 200 years. Prior to the arrival into Europe and North America of the parasitic mite Varroa destructor, AFB was the most economically important disease of honeybees. To date, AFB is the most infectious and destructive disease of honeybee brood and is often fatal for bee colonies (Genersch 2010). In Poland, AFB is the only notifiable disease of honeybees and is subject to obligatory combating (Buczek 2011). The final

Corresponding author: V. Isidorov, v.isidorov@pb.edu.pl

Manuscript editor: Stan Schneider decision regarding the method of combating (treating or destroying AFB colonies) is within the purview of the district veterinary surgeon.

The causative agent of this disease is the Grampositive, spore-forming bacterium Paenibacillus larvae, which is highly infectious. In some countries, antibiotics or sulfathiazole are used to combat AFB; however, these drugs only suppress the clinical symptoms and cannot cure the disease, because they are not effective against the infectious endospores (Genersch 2010). Furthermore, this practice leads to serious consequences, such as reduced honeybee vitality through the suppression of the endogenous microflora in these bees, the almost inevitable pollution of beekeeping products with medicinal residues, and the appearance of bacterial resistance (Lodesani and Costa 2005; Miyagi et al. 2000; Gende et al. 2010; Buczek 2011). Antibiotics and sulfathiazole are 
legally banned in the European Union for use in beekeeping (Mutinelli 2003), because honeybees are classed as farming animals, whose products cannot contain the residues of any drugs; therefore, this greatly limits the treatment possibilities.

Practically the only nonmedicinal method that is applied to sanitize infected colonies is the socalled shook swarm method (proposed in 1769 by Schirach), which consists of shaking adult bees onto a new uninfected comb foundation and destroying the old combs and other infected materials (Hansen and Brødsgaard 2003). This method can lead to positive results in the treatment of infected but not clinically diseased colonies (Genersch 2010). However, its application does not guarantee the complete recovery of treated bee colonies. Therefore, in recent decades, considerable attention has been paid to the development of alternative treatment methods, based on the application of natural antibacterial substances such as essential oils (Fuselli et al. 2008; Gende et al. 2008, 2009, 2010; González and Marioli 2010; Santos et al. 2012) or propolis (Antúnez et al. 2008; Bastos et al. 2008; Mihai et al. 2012; Bilikova et al. 2013; Wilson et al. 2015).

Propolis is a mixture of beeswax and resinous material that is collected by honeybees from various plants. In the mid-latitudes of the northern hemisphere, the plant precursor of propolis is the bud resins (exudates) of some arboreous trees, in particular, different species of poplar, aspen, and birch (Bankova et al. 2000; Wilson et al. 2013, 2015; Isidorov et al. 2014a, 2016). The antimicrobial activity of this natural antibiotic has been attributed to phenolic substances: flavonoid aglycones, and phenolic and hydroxycinnamic acids (Kujumgiev et al. 1999). Their specific content tends to vary to a great extent, depending on the plant precursor (Bankova et al. 2006).

Recent publications have demonstrated that the principal plant precursors of propolis from boreal and temperate zones of the European continent are the bud resins of black poplar (Populus nigra), downy birch (Betula pubescens), and common aspen (Populus tremula) (Isidorov et al. 2014a). In a more recent investigation, taxonomical markers of the resins from the buds of these trees were determined (Isidorov et al. 2016). Black poplar bud resin is characterized by a high content of phenols such as pentenyl (mostly, prenyl) cinnamates, chalcones, and the unsubstituted B ring flavonoids: pinocembrin, pinostrobin, chrysin, galangin, pinobanksin, and their 3-substituted derivatives (Isidorov and Vinogorova 2003). Downy birch and common aspen bud resins are distinguished by the presence of specific phenylpropenoids, hydroxycinnamic acid esters of sesquiterpene alcohols, and glycerol, respectively (Isidorov et al. 2014a, 2016). Although bees from the same colony often collect resins from more than one of these tree species, three main "types" of European propolis can be distinguished on the basis of the species-specific chemical composition: poplar-, birch-, and aspen-type (Popova et al. 2012; Isidorov et al. 2014a, 2016). Probably, the differences in the chemical composition are reflected in the antimicrobial activity of different "types" of propolis; however, little is known about the effects of different types of European propolis on P. larvae.

The main aim of this communication was to compare the in vitro anti-P. larvae action of three types of propolis from the temperate zone of the northern hemisphere in an attempt to relate the observed minimal inhibition concentration (MIC) values with the chemical composition of these bee products.

\section{MATERIALS AND METHODS}

\subsection{Chemicals and propolis}

Pyridine, bis(trimethylsilyl)trifluoroacetamide (BSTFA), and $\mathrm{C}_{8}-\mathrm{C}_{40} n$-alkane calibration standards were purchased from Sigma-Aldrich, (Poznań, Poland). Extractions were carried out with diethyl ether (POCH SA, Gliwice, Poland).

Two propolis samples (Pr-1 and Pr-2) were collected in the same apiary located in northeastern Poland, on the outskirts of Białowieza National Park $\left(52^{\circ}, 42^{\prime} \mathrm{N}, 23^{\circ}, 52^{\prime} \mathrm{E}\right)$. Propolis Pr-3 originated from the forest-steppe in the Volgograd region, Russia ( $48^{\circ} 48^{\prime} \mathrm{N}, 44^{\circ} 28^{\prime} \mathrm{E}$ ). Sample Pr-4 was supplied from the Słovak Republic ( $\left.48^{\circ} 44^{\prime} \mathrm{N}, 19^{\circ} 08^{\prime} \mathrm{E}\right)$. Three Russian samples originated from the taiga zone: propolis Pr-5 was collected in the Perm' region $\left(57^{\circ} 40^{\prime} \mathrm{N}\right.$, $56^{\circ} 12^{\prime} \mathrm{E}$ ), while Pr-6 and Pr-7 samples were received from apiaries in the Vologda region 
$\left(59^{\circ} 58^{\prime} \mathrm{N}, 38^{\circ} 31^{\prime} \mathrm{E}\right.$ and $\left.59^{\circ} 47^{\prime} \mathrm{N}, 38^{\circ} 38^{\prime} \mathrm{E}\right)$. Sample Pr- 8 originated from Finland $\left(61^{\circ} 43^{\prime} \mathrm{N}\right.$, $25^{\circ} 26^{\prime} \mathrm{E}$ ), and sample Pr-9 was supplied from northeastern Latvia (57 8.5 $\left.\mathrm{N}, 26^{\circ} 27^{\prime} \mathrm{E}\right)$.

Propolises Pr-1, Pr-2, and Pr-9 were collected by the authors in the summer of 2015. To acquire the material, a special net (mesh size of $1 \mathrm{~mm}$ ) was mounted just above the hive frames with the brood. After a time interval of 3 weeks, the net became fully glued with pure propolis by the bees. The propolis was easily separated after cooling the net to $-18{ }^{\circ} \mathrm{C}$. The remaining samples $(10-15 \mathrm{~g}$ each) were gathered in the summer of 2015 by apiarists in different countries. Propolis was harvested by scraping it off the frames or by using a plastic screens which were placed on the topmost frames in the hive and leaved until the bees have deposited propolis in the splits in the screen.

\subsection{Extract preparation and analyses}

Two grams of ground propolis powder was transferred to a $100 \mathrm{~mL}$ retort and extracted with three $50 \mathrm{~mL}$ portions of diethyl ether for $24 \mathrm{~h}$. The joint extracts were filtered through paper filter, and the solvent was removed using a rotary evaporator. The dry residue was used for chemical analysis and antibacterial tests.

About $5 \mathrm{mg}$ of the residue was diluted with $220 \mu \mathrm{L}$ of pyridine and $80 \mu \mathrm{L}$ of BSTFA. The mixture was sealed and heated for $30 \mathrm{~min}$ at $60{ }^{\circ} \mathrm{C}$ to form trimethylsilyl (TMS) derivatives. TMS derivatives were analyzed using GC-MS on an HP 6890 gas chromatograph fitted with an MSD 5973 mass selective detector (electron impact source and quadrupole analyzer) from Agilent Technologies (USA). This device was equipped with an HP-5MS fused silica column (30 $\mathrm{m} \times 0.25 \mathrm{~mm}$ i.d., $0.25-\mu \mathrm{m}$ film thickness) with electronic pressure control and a split/splitless injector. The latter was used at $250{ }^{\circ} \mathrm{C}$ in split (1:50) mode. The helium flow rate through the column was $1 \mathrm{~mL} \mathrm{~min}{ }^{-1}$ in constant flow mode. The column was charged with $1 \mu \mathrm{L}$ of the liquid sample containing about $0.3 \mu \mathrm{g}$ of derivatized components. The analysis was carried out with temperature programming from 50 to $310^{\circ} \mathrm{C}$ at a rate of $5{ }^{\circ} \mathrm{C} \min ^{-1}$; the highest temperature was maintained for $15 \mathrm{~min}$. The MSD detector acquisition parameters were as follows: the transfer line temperature was $280{ }^{\circ} \mathrm{C}$, the MS source temperature was $230^{\circ} \mathrm{C}$, and the MS quad temperature was $150^{\circ} \mathrm{C}$. The electron impact mass spectra were obtained at an ionization energy of $70 \mathrm{eV}$. The MSD was set to scan 41-600 amu.

After integration of the chromatogram, the fraction of each component in the total ion current (TIC) was calculated. The precision of the method was studied by three replicate extractions and analyses. The peak areas of the extract components obtained by replicate analyses were used for the calculation of their relative standard deviation (RSD) values. On average, RSD amounted to $2 \%$ for the main peaks (more than $10 \%$ of TIC), $6 \%$ for medium peaks (more than $1 \%$ of TIC), and $18 \%$ for peaks that amounted to $\leq 0.5 \%$ of TIC (Isidorov et al. 2016).

To identify the components, both mass spectral data and the calculated retention indices were used. Mass spectrometric identification was carried out with an automatic system of GC-MS data processing supplied by the NIST 14 library (NIST/EPA/NIH Library of Electron Ionization Mass Spectra containing 276,259 standard mass spectra) and a home-made library of mass spectra. The latter contains more than 1250 spectra of TMS derivatives prepared from commercial preparations of flavonoids, other phenolics, terpenoids, aliphatic and aromatic acids, and alcohols.

The linear temperature programmed retention indices $\left(I^{T}\right)$ were calculated from the results of the separation of $\mathrm{C}_{8}-\mathrm{C}_{40} n$-alkane solutions in hexane and the TMS derivatives. The measured values of the retention times were used to calculate the retention indices using the following equation:

$$
I^{T}=100\left(\mathrm{t}_{x}-\mathrm{t}_{n}\right) /\left(\mathrm{t}_{n+1}-\mathrm{t}_{n}\right)+100 \mathrm{n}
$$

where $t_{x}, t_{n}$, and $t_{n+1}$ are the retention times of compound $x$ and $n$-alkanes with the number of carbon atoms in the molecule $n$ and $n+1$, respectively $\left(t_{n} \leq t_{x} \leq t_{n+1}\right.$ ) (Van den Dool and Kratz 1963).

The obtained $I^{T}$ values were compared with the NIST collection (NIST 2013) as well as with the authors' previously published data (Isidorov et al. 2009, 2014a, b; Isidorov 2015) and presented in a home-made computer database containing more than $18,000 I^{T}$ values for more than 5500 organic 
compounds. The identification was considered reliable if the results of the computer search of the mass spectra library were confirmed by the experimental $I^{T}$ values, i.e., if their deviation from the homemade database values did not exceed \pm 5 u.i. (the highest quantity of intra-laboratorial deviation).

\subsection{P. larvae isolates}

P. larvae was isolated from honeybee larvae and honey samples originating from apiaries in southeastern Poland (Table I). To isolate the bacilli, dead larvae were aseptically removed from brood combs and were crushed and suspended in $5 \mathrm{~mL}$ of physiological saline $(0.9 \% \mathrm{NaCl})$, followed by shaking for $10 \mathrm{~min}$ at room temperature. To isolate bacteria from honey samples, about $10 \mathrm{~mL}$ of honey was preheated at $45^{\circ} \mathrm{C}$, diluted with sterile water in a ratio of $1: 1$, and centrifuged at $3000 \times g$ for $30 \mathrm{~min}$. The resulting pellets were suspended in $200 \mu \mathrm{L}$ of physiological saline. The solutions of crushed larvae and honey were centrifuged at $10,000 \mathrm{rcf}$ for $5 \mathrm{~min}$, and the resulting pellet was then suspended in $900 \mu \mathrm{L}$ of physiological saline. All samples were preheated in a water bath for $10 \mathrm{~min}$ at $85{ }^{\circ} \mathrm{C}$ to eliminate vegetative cells and to select the endospores. After preparation of a serial dilution $\left(10^{-1}-10^{-4}\right), 100 \mu \mathrm{L}$ of each solution was spread onto Columbia Blood Agar Base supplemented with vitamin $\mathrm{B}_{1}$ (Oxoid, Basingstoke, England) and incubated at $30{ }^{\circ} \mathrm{C}$ in $5 \% \mathrm{CO}_{2}$ for $48-96 \mathrm{~h}$. The bacteria that formed round colonies with a diameter of about $2-3 \mathrm{~mm}$ and that were transparent or slightly whitish, with an elevated center and frayed edge, were initially selected as $P$. larvae and were cultivated on the same medium and under the same conditions mentioned above to obtain pure cultures. The bacilli

Table I. Paenibacillus larvae isolates used in the study.

\begin{tabular}{llll}
\hline Name of isolate & Origin & Country & Region \\
\hline KB25 & Larvae & Poland & Lubelskie \\
KB35 & Larvae & Poland & Lubelskie \\
KB41 & Honey & Poland & Podkarpackie \\
KB55 & Larvae & Poland & Podkarpackie \\
\hline
\end{tabular}

initially classified as $P$. larvae were further investigated by Gram staining, the catalase test (Neuendorf et al. 2004), and a Plagemann probe. Gram-positive and catalase-negative bacilli that formed spiral forms in the Plagemann probe were classified as P. larvae (Plagemann 1985). The selected strains were kept at $-80{ }^{\circ} \mathrm{C}$ in MuellerHinton broth (Oxoid) supplemented with glycerol at a ratio of 1:1.

\subsection{S rRNA gene sequencing}

Total DNA was prepared from overnight cultures of the isolates grown in a brain-heart infusion (BHI) broth using the protocol for Grampositive bacteria with the DNeasy Blood \& Tissue Kit (Qiagen GmbH, Hilden, Germany) and the Qiacube apparatus (Qiagen), according to the instruction manuals. The DNA concentration and purity were checked using a NanoDrop 2000 spectrometer (Thermo Fisher Scientific Com., Waltham, USA). The partial $16 S$ rRNA gene of the isolates was amplified using a pair of primers: Pl-16SE1 5'-GCA AGT CGA GCG GAC CTT GTG-3' and P1-16SE2 5'-AAA CCG GTC AGA GGG ATG TCA AG-3' (Neuendorf et al. 2004) in a PCR reaction using the Expand Long Template PCR System (Roche Diagnostic $\mathrm{GmbH}$, Mannheim, Germany) as follows: $94^{\circ} \mathrm{C}$ for $3 \mathrm{~min}, 94^{\circ} \mathrm{C}$ for $30 \mathrm{~s}, 50^{\circ} \mathrm{C}$ for $45 \mathrm{~s}$, and $68^{\circ} \mathrm{C}$ for $7 \mathrm{~min}$. The 966-bp $16 \mathrm{~S} r R N A$ amplicons were cloned into pGEM-T Easy (Promega Corporation, Madison, USA). To determine the accuracy of the sequence, both strands of two clones were sequenced using $\mathrm{T} 7$ and SP6 primers, in an ABI3500 automated sequencer (Applied Biosystems, Foster City, USA). For the comparative analyses of nucleotide and amino acid sequences, database searches were performed using the BLAST program at the NCBI website (http://www.ncbi.nlm.nih.gov). This study confirmed the identification of isolates KB25, $\mathrm{KB} 35, \mathrm{~KB} 41$, and $\mathrm{KB} 55$ as P. larvae.

\subsection{Anti-P. larvae susceptibility test}

The propolis extracts were tested against four "wild" P. larvae isolates, as well as against the reference $P$. larvae LMG 09820 strain (Belgian 
Coordinated Collections of Microorganisms). The latter was isolated in 1906 from a foul brood of honeybees by White as Bacillus larvae (White 1906); this was reclassified several times and was finally named Paenibacillus larvae (Heyndrickx et al. 1996). The bacterial strains kept at $-80{ }^{\circ} \mathrm{C}$ were inoculated onto blood agar (Oxoid) and were incubated for $48 \mathrm{~h}$ at $30{ }^{\circ} \mathrm{C}$. Then, bacteria were reinoculated onto Mueller-Hinton broth and cultured until they reached an optical density of $0.2-$ 0.4 at $600 \mathrm{~nm}$, measured with a V-670 spectrophotometer (Jasco, Japan).

The propolis extracts were dissolved in DMSO at a concentration of $2 \mathrm{mg} \mathrm{mL}^{-1}$, sonicated in a Branson 2510 ultrasonic bath (Sigma), and filtered through a $0.22-\mu \mathrm{m}$ pore size Rotilabo-Spritzenfilter filter (Carl Roth $\mathrm{GmbH}$ and Co, Karlsruhe, Germany). To maintain appropriate nutrient conditions, the extracts were aseptically diluted in doubleconcentrated Mueller-Hinton broth using laboratory tubes that contained an arithmetic dilution series ranging from 0.5 to $1000 \mu \mathrm{g} \mathrm{mL}^{-1}$ in a final volume of $3 \mathrm{~mL}$. The propolis solutions used in the study were as follows: $0.5,1.0,2.0,3.9,7.8,15.6,31.2$, $62.5,125.0,250,500$, and $1000 \mu \mathrm{g} \mathrm{mL}^{-1}$. In order to observe whether the solvent alone caused turbidity of the medium, we included a solvent control.

The minimal inhibitory concentration (MIC) of the extracts was assessed in the tube dilution test in accordance with Clinical and Laboratory Standard Institute (2011) protocols. For the assay, $30 \mu \mathrm{L}$ of the bacterial culture of an $\mathrm{OD}_{600} \sim 0.4$ was added to each tube with the extract and was incubated for $48 \mathrm{~h}$ at $37^{\circ} \mathrm{C}$. The bacterial cultures with different concentrations of propolises were observed visually. The lowest dose of the extract with no growth of $P$. larvae was regarded as the MIC value. All the tests were repeated four times. Cultures of $P$. larvae in tubes with MuellerHinton broth without propolis extracts were used as a positive control. Mueller-Hinton broth supplemented with $10 \%$ DSMO arithmetically diluted ranging from 0.0025 to $5 \%$ was used as a solvent control. Similar growth of bacteria under study in Mueller-Hinton broth without DMSO (positive control) and in Mueller-Hinton broth supplemented with 10\% DSMO (solvent control) was observed, which allowed to conclude that DMSO itself does not affected P. larvae growth.

\section{RESULTS}

The composition of diethyl ether extracts of propolis was very complex: on the chromatograms of nine samples of propolis from five European countries (Figure 1), 278 organic components were recorded, 141 of which belonged to different groups of aromatic compounds. More comprehensive groups were formed by flavonoids and chalcones (53 unique chromatographic peaks) and by phenylpropenoids (63 unique peaks for cinnamic acid derivatives). Apart from hydroxycinnamic acids and their benzyl and pentenyl esters (36 peaks), phenylpropenoids were also represented by the hydroxycinnamoyl esters of sesquiterpene $\mathrm{C}_{15} \mathrm{H}_{24} \mathrm{O}$ alcohols (10 peaks), as well as monoglycerides and diglycerides of $p$ coumaric, ferulic, and caffeic acids (17 peaks). Furthermore, all propolis samples contained several terpenoids in different amounts: the chromatograms showed the presence of $\mathrm{C}_{15} \mathrm{H}_{24} \mathrm{O}, \mathrm{C}_{15} \mathrm{H}_{26} \mathrm{O}$, and $\mathrm{C}_{15} \mathrm{H}_{24} \mathrm{O}_{2}$ sesquiterpenoids (39 peaks), and $\mathrm{C}_{30} \mathrm{H}_{48} \mathrm{O}, \mathrm{C}_{30} \mathrm{H}_{50} \mathrm{O}$, and $\mathrm{C}_{30} \mathrm{H}_{50} \mathrm{O}_{2}$ triterpenoids (19 peaks). In general, the qualitative composition of the samples under investigation corresponded well with previously published data on European propolis (Bankova et al. 2000, 2006; Isidorov et al. 2014a). Table II presents the group composition of extracts in terms of their proportion of the total ion current (TIC) of the chromatogram.

The specific features of the qualitative composition of the propolis samples under investigation led to the conclusion that among the nine samples listed in Table II, only three, i.e., Pr-1, Pr-5, and Pr9 , were selectively collected by honeybees from a single plant source. The propolis Pr-1 was almost a pure poplar-type propolis, Pr-5 was a birch type, and Pr-9 was an aspen-type propolis. Samples Pr2, Pr-3, and Pr-4 also belonged to the poplar-type; however, they contained a relatively small admixture (0.6-1.0\% of TIC) of phenylpropenoid glycerides, which are taxonomical markers of aspen bud resin (Isidorov et al. 2009). Samples Pr-6 and Pr-7 of Russian propolis were birch-type, but contained marked amounts (2.4 and $7.8 \%$ of TIC) of aspen resin-derived phenylpropenoid glycerides. Aspen-type propolis Pr-8 contained an admixture $(2.5 \%$ of TIC) of typical downy birch phenylpropenoid sesquiterpenols. 


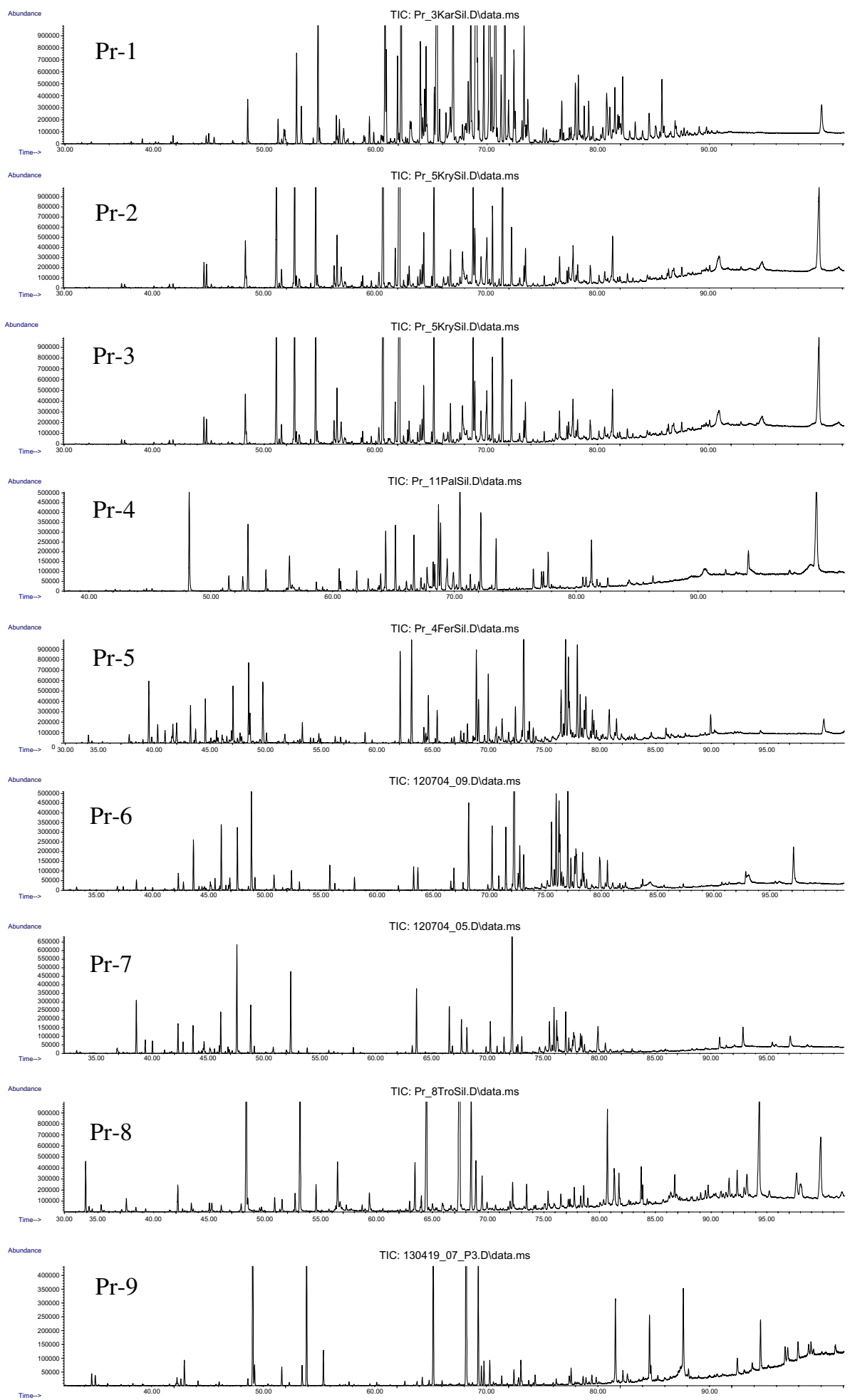

Figure 1. GC-MS chromatograms of diethyl extracts of propolis samples Pr-1 to Pr-9. 


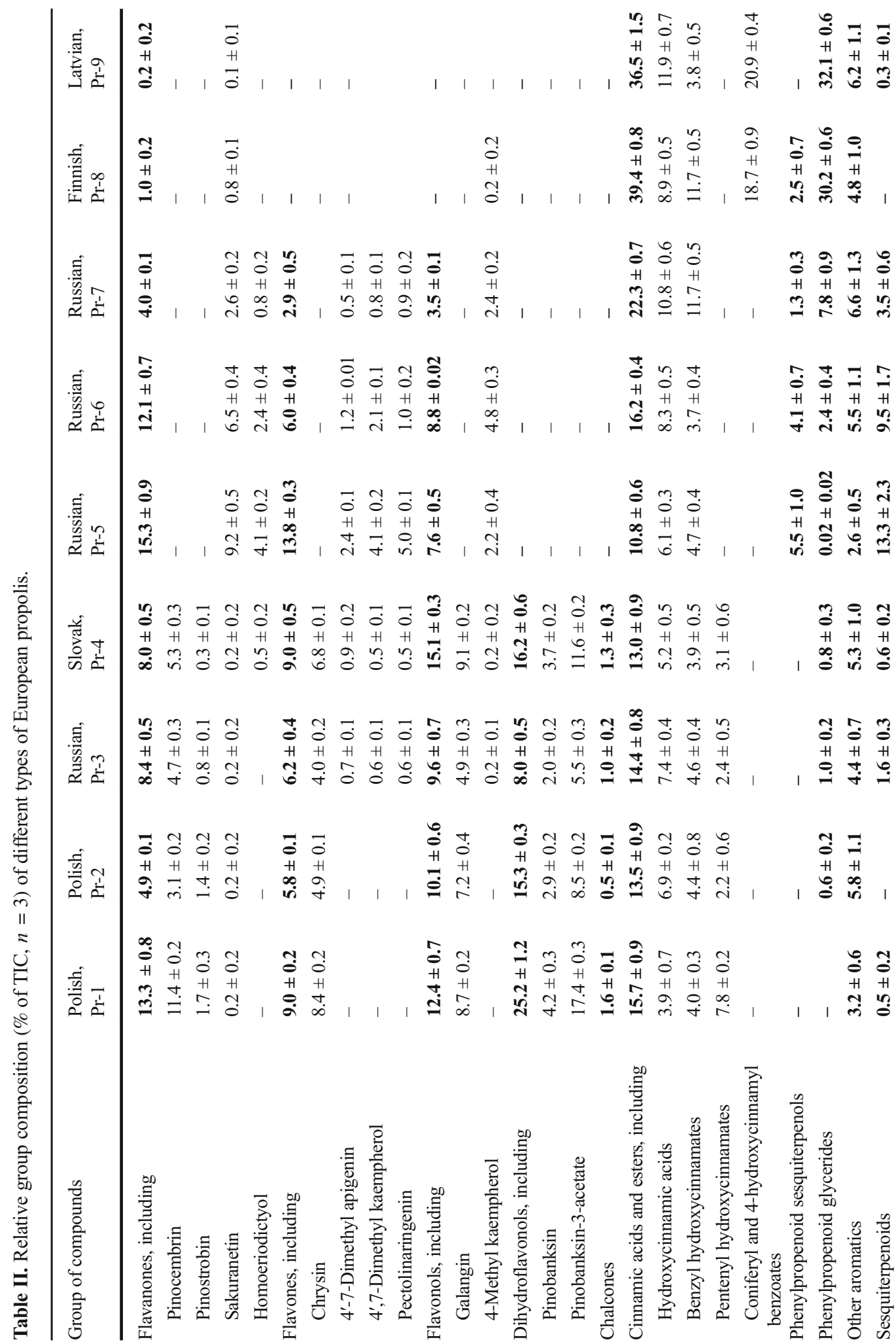




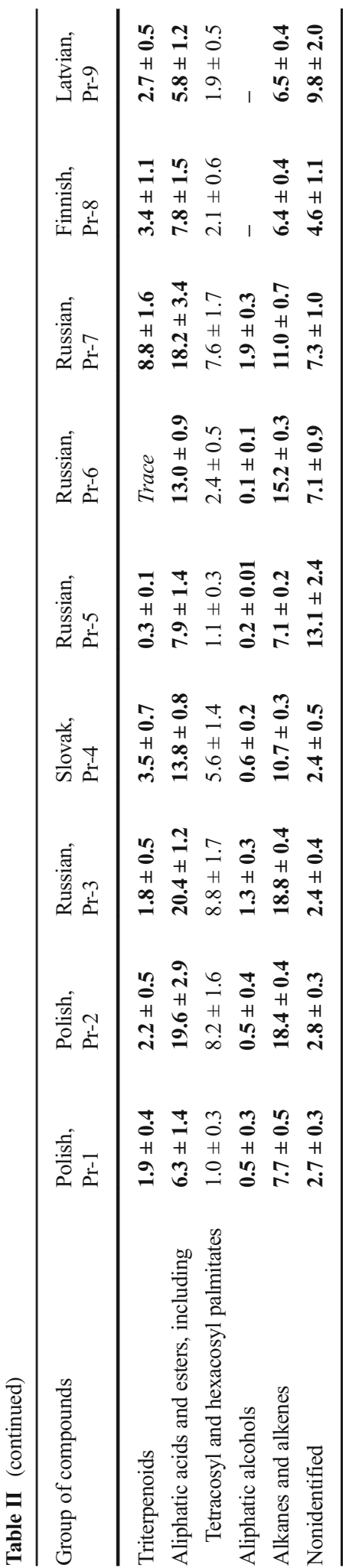

Hierarchical cluster analysis was performed based on chemical data (Table II). As shown in Figure 2, nine propolis samples can be separated into three groups. Samples Pr-2, Pr-3, Pr-4 form one group harvested from poplar buds. Pure poplar-type sample Pr-1 belong to the same group, showing a difference from other samples of this group with small admixtures $(0.6-1.0 \%)$ of aspen bud resins. Samples Pr-5, Pr-6, and Pr-7 were grouped as another group harvested presumably from birch buds. A slight difference shows sample Pr-5 which contains the least admixture of aspen resins. The third group was formed of samples Pr8 and Pr-9 harvested from aspen buds, which are considerably different from other samples in antiP. larvae activity (see below).

To test the antimicrobial activity of the propolis extracts, we used the tube dilution assay. The sensitivity of the "wild" isolates and reference LMG 09820 strain of $P$. larvae were tested. The minimal inhibitory concentrations of the propolis extracts are presented in Table III. The most active was the Polish poplar-type propolis Pr-1, which showed MIC values that ranged from 7.8 to $15.6 \mu \mathrm{g} \mathrm{mL}^{-1}$. In contrast, the Latvian pure aspen-type propolis Pr-9 showed lower antimicrobial activity (from 31.8 to $62.5 \mu \mathrm{g} \mathrm{mL}^{-1}$ ) against all tested strains.

\section{DISCUSSION}

It is relevant to ascertain how the chemical composition of different propolis types influences their activity against $P$. larvae. As can be observed in Table III, despite qualitative and quantitative differences in their composition, all tested extracts significantly inhibited the growth of the Polish isolates and the reference strain of $P$. larvae with MIC values ranging from 7.8 to $62.4 \mu \mathrm{g} \mathrm{mL}^{-1}$.

The investigated poplar-type propolis $(\mathrm{P}-1$ to P-4) showed practically identical effects on the pathogen, which is not surprising considering that their qualitative composition was very similar. Moreover, the quantitative compositions of the biologically active phenols in P-1 to P-4 were similar if the lipophilic wax components were excluded. Therefore, the slightly higher activity of Pr-1 with a MIC value of $7.8 \mu \mathrm{g} \mathrm{mL}^{-1}$ in the assay with $\mathrm{KB} 25$, KB35, and KB41 isolates might be due to the lower (compared to propolis samples 


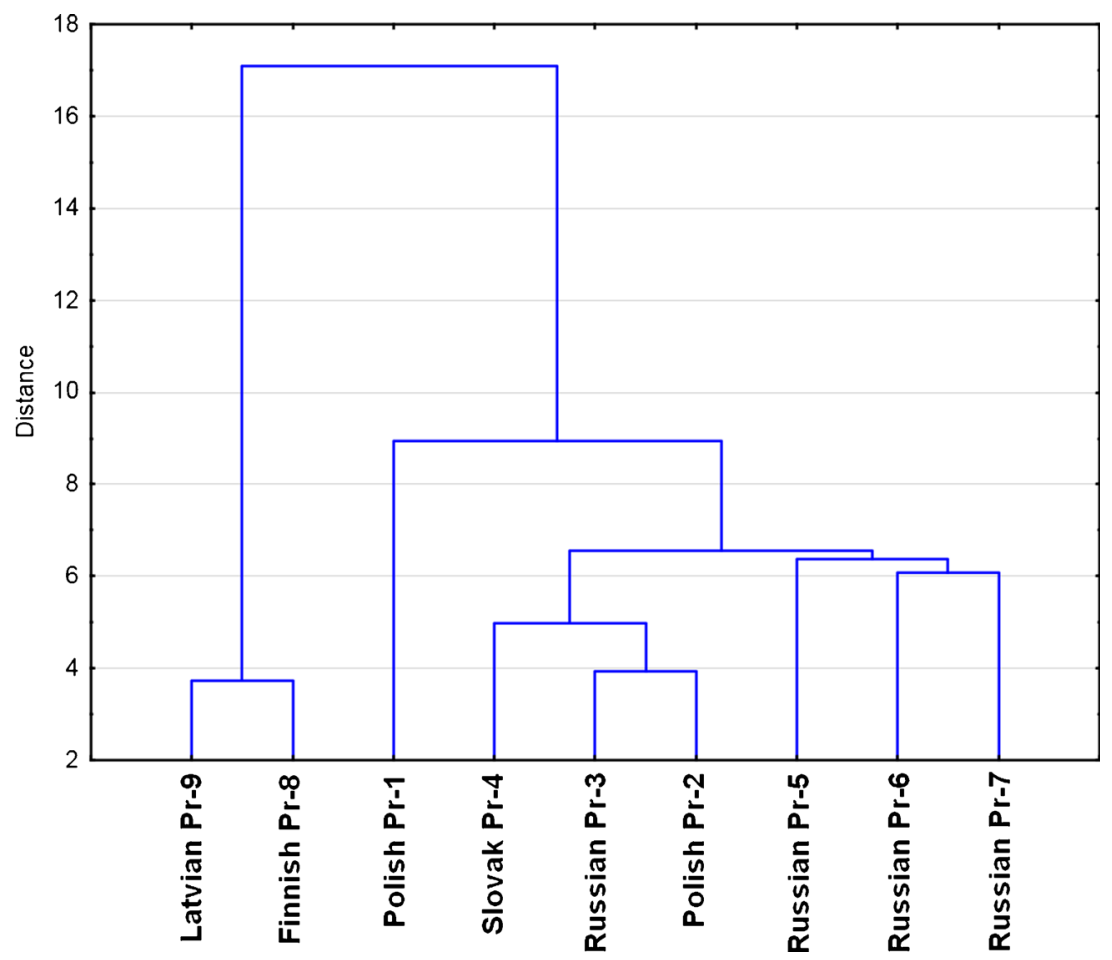

Figure. 2 Hierarchical cluster analysis of propolis samples based on their chemical composition.

Pr-2 to Pr-4) relative content of "neutral" wax components such as saturated fatty acids and their esters with saturated aliphatic alcohols $(6.3 \%$ of
TIC), alkanes, and alkenes (7.7\% of TIC), which do not influence the biological activity of propolis. Notably, samples Pr-1 and Pr-2 were collected

Table III. Minimal inhibitory concentration of different extracts for P. larvae.

\begin{tabular}{lccccc}
\hline Propolis & \multicolumn{2}{l}{ MIC $\left(\mu \mathrm{g} \mathrm{m}^{-1}\right)$ for P. larvae strains } & & \\
\cline { 2 - 5 } & $\mathrm{KB} 25$ & $\mathrm{~KB} 35$ & $\mathrm{~KB} 41$ & $\mathrm{~KB} 55$ & LMG 09820 \\
\hline Poplar type & & & & & \\
Pr-1 (Poland-1) & 7.8 & 7.8 & 7.8 & 15.6 & 15.6 \\
Pr-2 (Poland-2) & 15.6 & 15.6 & 15.6 & 15.6 & 15.6 \\
Pr-3 (Russia-1) & 15.6 & 15.6 & 15.6 & 15.6 & 15.6 \\
Pr-4 (Slovak) & 15.6 & 15.6 & 15.6 & 15.6 & 15.6 \\
Birch type & & & & & 15.6 \\
Pr-5 (Russia-2) & 15.6 & 15.6 & 15.6 & 15.6 & 15.6 \\
Pr-6 (Russia-3) & 15.6 & 31.8 & 15.6 & 31.8 & 31.8 \\
Pr-7 (Russia-4) & 15.6 & 31.8 & 15.6 & & 31.8 \\
Aspen type & & & & 15.6 & 62.4 \\
Pr-8 (Finland) & 31.8 & 31.8 & 15.6 & 62.4 & \\
Pr-9 (Latvia) & 31.8 & 62.4 & 31.8 & & \\
\hline
\end{tabular}


at the same time by honeybees inhabiting neighboring hives. It appears that one of the two bee colonies, for unknown reasons, added more waxes to the collected poplar bud resins.

The high anti-P. larvae activity of the poplar-type and birch-type propolis can be attributed to the high content of flavonoids, which is consistent with recent findings (Popova et al. 2007; Mihai et al. 2012; Bilikova et al. 2013). However, a substantial difference in the composition of the flavonoid fraction of these two types of propolis was notable. The products derived from poplar bud resin contained large amounts of dihydroflavonols (pinobanksin and its 3substituted derivatives) and the flavanones pinocembrin and pinostrobin, which were completely absent in birch-type propolis (Table II). On the contrary, only small amounts of the main birch-bud flavanone sakuranetin was present in poplar-type propolis. Sakuranetin and another flavanone, homoeriodictyol, as well as the flavone pectolinaringenin can be considered as taxonomic markers of downy birch (B. pubescens) on par with phenylpropenoid sesquiterpenols (Isidorov et al. 2014b, 2016). These flavonoids possess antimicrobial activity (Atkinson and Blakeman 1982; Grecco et al. 2014). Therefore, they may contribute to the spectrum of biological activity of propolis from the boreal zone of Europe, including anti- $P$. larvae action.

Although they only contained trace amounts of flavonoids, the aspen-type samples of propolis were active against $P$. larvae (Table III). This activity can be attributed to other phenols, i.e., hydroxycinnamyl glycerides. This hypothesis needs experimental confirmation; phenylpropenoid glycerides have demonstrated antitumor, antiproliferative, and estrogenic activity (Banskota et al. 2002; Cheng et al. 2007; Gunasekera et al. 1981), although their antimicrobial properties have not been previously investigated. Notably, aspen-type $\operatorname{Pr}-8$ propolis, containing an admixture of birch bud-derived phenylpropenoid sesquiterpenols, was slightly more active than the pure aspen-type sample Pr-9.

These findings firstly assume that not only flavonoids but also different phenylpropenoids (such as phenylpropenoid glycerides, the main phenolics of aspen-type propolis) are also responsible for the antibacterial activity of propolis from the boreal zone. Secondly, the higher anti-P. larvae activity of Pr-8 propolis, which was "polluted" with components derived from birch bud resin, might provide evidence of a synergistic interaction among different compounds in propolis (Mihai et al. 2012). Resin diversity may be beneficial for bees with respect to protection against different pathogens (Drescher et al. 2014; Wilson et al. 2013, 2015). It is relevant and worthwhile to further study the interaction effects among phenols of different classes of propolis extracts.

Finally, a comparison of the results of investigations dealing with the in vitro anti-P. larvae action of essential oils and propolis confirmed the higher activity of propolis. For example, essential oils from four Citrus species demonstrated MIC values ranging from 385 to $840 \mu \mathrm{g} \mathrm{mL}^{-1}$ (Fuselli et al. 2008). According to Gende et al. (2008, 2009), relatively high MIC values (from 50 to $300 \mu \mathrm{g} \mathrm{mL}^{-1}$ ) also characterize essential oils from Lavandula officinalis, Cinnamomum zeylanicum, Mentha piperita, Pimpinella anisum, and Foeniculum vulgaris. Therefore, the application of propolis for nonmedicinal AFB treatment appears to be more promising.

\section{ACKNOWLEDGEMENTS}

The project was supported by the Grant of National Science Center (Poland) 2014/13/B/NZ7/02280.

Contributions VI-propolis collection and GC-MS analysis; $\mathrm{KB}-P$. larvae isolation and identification; $\mathrm{GZ}$ and IS - microbiological investigations; $\mathrm{KM}$ - participation in the design of the data

\section{OPEN ACCESS}

This article is distributed under the terms of the Creative Commons Attribution 4.0 International License (http://creativecommons.org/licenses/by/4.0/), which permits unrestricted use, distribution, and reproduction in any medium, provided you give appropriate credit to the original author(s) and the source, provide a link to the Creative Commons license, and indicate if changes were made.

Etude in vitro de l'activité anti-microbienne de propolis d'origine européenne vis-à-vis de Paenibacillus larvae

Paenibacillus larvae / loque américaine / Apis mellifera / propolis / action antibactérienne 
In vitro Studie zur antimikrobiellen Aktivität von europäischem Propolis gegenüber Paenibacillus larvae

\section{Paenibacillus larvae / Amerikanische Faulbrut / Apis mellifera / Propolis / antibakterialle Aktivität}

\section{REFERENCES}

Antúnez, K., Harriet, J., Gende, L., Maggi, M., Eguaras, M., Zunino, P. (2008) Efficacy of natural propolis extract in the control of American foulbrood. Vet. Microbiol. 131, 324-331

Atkinson, P., Blakeman, J.P. (1982) Seasonal occurrence of an antimicrobial flavanone, sakuranetin, associated with gland of leaves of Ribes nigrum. New Phytol. 92, 63-74

Bankova, V., Castro, S.L., Marcucci, M.C. (2000) Propolis: recent advances in chemistry and plant origin. Apidologie 31 , 3-15

Bankova, V., Popova, M., Trusheva, B. (2006) Plant sources of propolis: an update from a chemist's point of view. Nat. Prod. Commun. 1, 1023-1028

Banskota, A.H., Nagaoka, T., Sumioka, L.Y., Tezuka, Y. (2002) Antiproliferative activity of the Netherland propolis and its active principles in cancer cell lines. J. Ethnopharmacol. 80, 67-73

Bastos, E.M.A.F., Simone, M., Jorge, D.M., Soares, A.E.E., Spivak, M. (2008) In vitro study of antimicrobial activity of Brazilian propolis against Paenibacillus larvae. J. Invertebr. Pathol. 97, 273-281

Bilikova K., Popova, M., Trusheva, B., Bankova, V. (2013) New anti-Paenibacillus larvae substances purified from propolis. Apidologie 44, 278-285

Buczek, K. (2011) Range of susceptibility of Paenibacillus larvae to antibacterial compounds. Med. Vet. 67, 8790

Cheng, W.Y., Kuo, Y.H., Huang, C.J. (2007) Isolation and identification of novel estrogenic compounds in yam tuber (Dioscorea alata cv. Tainung no. 2). J. Agric. Food Chem. 55, 7350-7358

Drescher, N., Wallace, H.M., Katouli, M., Massaro, C.F., Leonhardt, S.D. (2014) Diversity matter: how bees benefit from different resin sources. Oecologia 176, 943-953

Fuselli, S.R., de la Rosa, S.B.G., Eguaras, M.J., Fritz, R. (2008) Chemical composition and antimicrobial activity of citrus essences on honeybee bacterial pathogen Paenibacillus larvae, the causal agent of American foulbrood. World J. Microbiol. Biotechnol. 24, 2067-2072

Gende, L.B., Principal, J., Maggi, M.D., Palacios, S.M., Fritz, R., Eguaras, M.J. (2008) Extracto de Melia azedarach y esenciales de Cinnamomum zeylanicum, Mentha piperita y Lavandula officinalis como control de Paenibacillus larvae. Zootec. Tropic. 26, $151-156$
Gende, L.B., Maggi, M.D., Fritz, R., Eguaras, M.J., Bailac, P.N., Ponzi, M.I. (2009) Antimicrobial activity of Pimpinella anisum and Foeniculum vulgare essential oils against Paenibacillus larvae subsp. larvae. J. Essent. Oil Res. 21, 91-93

Gende, L.B., Fernández, N., Buffa, F., Ruiu, L., Satta, A., Fritz, R., Eguaras, M.J., Floris, I., (2010) Susceptibility of Paenibacillus larvae isolates to tetracycline hydrochloride and cinnamon (Cinnamomum zeylanicum) essential oil mixture. Bull. Insectol. 63 , 247-250

Genersch, E. (2010) American foulbrood in honey bees and its causative agent, Paenibacillus larvae. J. Invertebr. Pathol. 103, S10-S19

González, M.J., Marioli, J.M. (2010) Antibacterial activity of water extracts and essential oils of various aromatic plants against Paenibacillus larvae, the causative agent of American foulbrood. J. Invertebr. Pathol. 104, 209-213

Grecco, S dos S., Dorigueto, A.C., Landre, I.M., Soares, M.G., Martho, K., Lima, R., Pascon, R.C., Vallim, M.A., Capello, T.M., Romoff, P., Sartorelli, P., Lago, J.H.G. (2014) Structural crystalline characterization of sakuranetin - an antimicrobial flavanone from twigs of Baccharis retusa (Asteraceae). Molecules 19, 75287542; doi:10.3390/molecules19067528

Gunasekera, S.P., Kinghorn, A.D., Cordell, G.A., Farnsworth, N.R. (1981) Plant anticancer agents. XIX. Constituents of Aquilaria malaccensis. J. Nat. Prod. 44, 569-572.

Hansen, H., Brødsgaard, C.J. (2003) Control of American foulbrood by shaking method. APIACTA 38, 140-145

Heyndrickx, M., Vandemuelebroecke, K., Hoste, B, Janssen, P., Kersters, K., De Vos, P., Logan, N.A., Berkeley, R.C. (1996) Reclassification of Paenibacillus (formerly Bacillus) pulvifaciens (Nakamura 1984) Ash et al. 1994, a later subjective synonym of Paenibacillus (formerly Bacillus) larvae (White 1906) Ash et al. 1994, as a subspecies of $P$. larvae, with emended descriptions of $P$. larvae as $P$. larvae subsp. larvae and $P$. larvae subsp. pulvifaciens. Int. J. Syst. Bacteriol. 46, 270-279

Isidorov, V.A., Vinogorova, V.T. (2003) GC-MS analysis of compounds extracted from buds of Populus balsamifera and Populus nigra. Z. Naturforsch. 58c, $355-360$

Isidorov, V.A., Brzozowska, M., Czyżewska, U., Glinka, Ł. (2009) Gas chromatographic investigation of phenylpropenoid glycerides from aspen (Populus tremula L.) buds. J Chromatogr A 1198-1199, 196-201

Isidorov, V., Szczepaniak, L., Bakier, S. (2014a) Rapid GC/ MS determination of botanical precursors of Eurasian propolis. Food Chem. 142, 101-110

Isidorov, V., Szczepaniak, L., Wróblewska, A., Pirożnikow, E., Vetchinnikova, L. (2014b) Gas chromatographicmass spectrometric examination of chemical composition of two Eurasian birch (Betula L.) bud exudate and its taxonomical implication. Biochem. System. Ecol. 52, 41-48

Isidorov, V.A. (2015) Identification of biologically and environmentally significant organic compounds. Mass 
spectra and retention indices of trimethylsilyl derivatives. PWN, Warsaw, $430 \mathrm{pp}$.

Isidorov, V.A., Bakier, S., Pirożnikow, E., Zambrzycka, M., Swiecicka, I. (2016) Selective behaviour of honeybees in acquiring European propolis plant precursors. J. Chem. Ecol. DOI: 10.1007/s10886-016-0708-9

Kujumgiev, A., Tsvetkova, I., Serkedjieva, Y., Bankova, V., Christov, R., Popov, S. (1999) Antibaterial, antifungal and antiviral activity of propolis of different geographic origin. J. Ethnopharmacol. 64, 235-240.

Lodesani, M., Costa, M. (2005) Limits of chemotherapy in beekeeping: development of resistance and problem of residues. Bee World 86, 102-109

Mihai, C.M., Mărghitaș, L.A., Dezmirean, D.S., Chirilă, F., Moritz R.F.A., Schlüns H. (2012) Interaction among flavonoids of propolis affect antibacterial activity against the honeybee pathogen Paenibacillus larvae. J. Invertebr. Pathol. 110, 68-72

Miyagi, T., Peng, C.Y.S., Chuang, R.,Y., Mussen, E.C., Spivak, M.S. (2000) Verification of tetracyclineresistant American foulbrood pathogen Paenibacillus larvae in the United States. J. Invertebr. Pathol. 75, 95-96

Mutinelli, F. (2003) Practical application of antibacterial drugs for the control of honeybee diseases. Apiacta 38, 149-155.

Neuendorf, S., Hedtke, K., Tangen, G., Genersch, E. (2004) Biochemical characterization of different genotypes of Paenibacillus larvae subsp. larvae, a honey bee bacterial pathogen. Microbiology 150, 2381-2390

NIST Chemistry WebBook, National Institute of Standards and Technology, Gaithersburg (2013), MD 20899: http://webbook.nist.gov. chemistry

Plagemann, O. (1985) A simple culture method for the bacteriological identification of Bacillus larvae on
Columbia blood slant agar. Berliner und Münchener Tierärztliche Wochenschrift 98, 61-62

Popova, M.P., Bankova, V.S., Bogdanov, S., Tsvetkova, I., Naydenski, C., Marcazzan, G.L., Sabatini, A.-G. (2007) Chemical characteristics of poplar type propolis of different geographic origin. Apidologie 38, 306311

Popova, M., Trusheva, B., Khismatullin, R., Gavrilova, N., Legotkina, G., Lyapunov, J., Bankova, V. (2012) The triple botanical origin of Russian propolis from the Perm Region, its phenolic content and antimicrobial activity. Nat. Prod. Commun 7, 617-621

Santos, R.C.V., dos Santos Alves, C.F., Schneider, T., Lopes, L.Q.S., Aurich, C., Giongo, J.L., Brandelli, A., de Almeida Vaucher, R. (2012) Antimicrobial activity of Amazonian oils against Paenibacillus species. J. Invertebr. Pathol. 109, 265-268

Van den Dool, H., Kratz, P.G. (1963) A generalization of the retention index system including linear temperature programmed gas liquid partition chromatography. J. Chromatogr. 11, 463-471

White, G.F. (1906) The bacteria of the apiary, with special reference to bee diseases. Bureau of Entomology Technical Series no. 14. U.S. Department of Agriculture, Washington, D.C.

Wilson, M.B., Spivak, M., Hegeman, A.D., Rendahl, A., Cohen, J.D. (2013) Metabolomics reveals the origins of antimicrobial plant resins collected by honey bees. PLoS One 8(10): e77512, doi:10.1371/journal. pone.0077512

Wilson, M.B., Brinkman, D., Spivak, M., Gardner, G., Cohen, J.D. (2015) Regional variation in composition and antimicrobial activity of US propolis against Paenibacillus larvae and Ascosphaera apis. J. Invertebr. Pathol. 124, 44-50 